\title{
MADURESE DEVERBAL NOMINALIZATION PROCESS
}

\author{
${ }^{a} A$ lfin Fuji Hidayati, ${ }^{b}$ Ika Nurhayani, ${ }^{\text {Nurul Choyimah }}$ \\ Universitas Brawijaya, Malang \\ e-mail: Alfinfuji633@gmail.com
}

\begin{abstract}
Nominalizations can be structured by adding affixes before or after root to create new words in language. Madurese has several language aspects that have not been widely explored. Previous linguistic studies on Madurese mostly focused on morphological aspects such as Madurese affixation in general. Therefore, this research discusses Madurese Deverbal Nominalization Process (Noun Derived from Verb). The goals of this research are to identify what types of affixes which form deverbal nouns in Madurese and to know how the affixation process that forms the deverbal nouns in Madurese. For example: pa-mandi-an, the root is mandi (take a shower) after it attachés to confix ( $p a--a n)$ the word class category changes to noun pa-mandi-an, that is a bath room. This research is a descriptive qualitative research, and the data were collected from a Madurese short story entitled Tora (satengkes carpan Madura), which was written by Jamal D. Rahma (2017). The findings are presented descriptively by identifying the process of the derivational forming nouns. The results of this research shows that prefixes, suffixes, confixes and infixes are contributed to create new lexemes in Madurese.
\end{abstract}

Keywords: Morphological approach, Deverbal Nominalization, Derivational Affixes. 


\section{INTRODUCTION}

Many linguists have been interested in conducting research about local languages. One local language that attracts the writer's attention is Madurese because the research about Madurese which is concerned with nominalization process is still lacking. Nominalization is where verbs and adjectives are linguistically realized as noun (Halliday, cited in Adu, 1985). It means, a verb or an adjective can turn into a noun when affixes are attached to them. Okatvianti, et al., (2019) stated that one of the main word classes is nominalization. It is used to arrange a clause and sentence. It means that the basic form to build a simple or complex sentence needs a noun and a verb. Hence, there are many ways to create new words and change the meaning, such as deverbal nominalization. It is supported by Grimshaw, (2020) who stated deverbal nominalization is a way to arrange new meaning and it is commonly complex because it will have various of meanings. The nouns which are derived from verbs are consideredto have a wide range of meanings and denoted to create concrete objects, actions, events, manners, process etc.

Most of previous researchers discuss about Madurese of Affixation generally. Related to the previous studies, it requires leading the current research which deals with affixation focusing on derivational affixation forming deverbal nouns or it is known as nominalization. This research aims to discuss about Nominalization process or Derivational affixed forming deverbal noun in Madura short story "Tora (satengkes carpan Madura)" that was written by Jamal D. Rahma (2017). Davies (2010) argued that verbs which have additional affixes in Madurese will form a new vocabulary, such as; nouns, adjectives and so on. This also happens to other languages, such as English, Batak language and so forth. It means that a noun is a central unit in a sentence to complete the meaning. The following is an example of Deverbal nouns in Madurese:

$$
\begin{array}{lll}
\text { Dhateng }=\text { come }(\mathrm{V}) & \rightarrow & \text { Kadhatengan }=\operatorname{arrival}(\mathrm{N}) \\
\text { Terro }=\text { want }(\mathrm{V}) & \rightarrow & \text { Pangaterro }=\text { wish }(\mathrm{N}) \\
\text { Lako }=\text { work }(\mathrm{V}) & \rightarrow & \text { Lakona }=\text { work, job }(\mathrm{N})
\end{array}
$$

From those examples of affix $k a-, p a-, n g a-$, and -an, it is clearly stated that those affixes can change the word classes and the meaning from the root of the word. It is noticed that the process of nominalization in Madurese requires to be discussed further. Besides the topic of nominalization in Madurese is still rarely done, the author also would like to resuscitate that Madurese deserves to be introduced so that there is no language shift.

Several previous studies discussed about affixes in Madurese. However, they do not specify their research at all. Muslimah et al., (2019) found that Madurese has four affixes; prefixes, suffixes, infixes and confixes. The previous study found that there are seven kinds of prefixes in Madurese; $-a,-e,-t a,-k a,-s a,-p a$, and $-p e$. Then, the suffixes are $e_{-}^{-}, a_{-}$, an-, en-, na-, ana-, and aghi-, so, there are seven suffixes which are found in Madurese language. Next, there are four infixes. Those are -al-, -ar-, -en-, and-om-. The last one is confix which has twelve confixes, ka-an, ka-na, ka-e, ka-en, ka-a-aghi, pa-an, sa-na, sa-an, a-an, a-ghi, e-aghi, and pa-aghi. The function of all affixes are changing the word classes into another word classes and its meaning.

However, research about deverbal noun or nominalization of other langauge had been done by Teo, 2013; Herawati, 2016; and (Yuniartati et al., 2017). The first one is Teo (2013) who investigated Tibeto-Burman language. On his research, Teo (2013) 
has demonstrated on how deverbal nouns are designed and defined by any accompanying tone changes. He intended to resist that the syllable structure of the verb plays vital role in deverbal nouns word-formation process. The next research was done by Herawati (2016) who analysed how affixed reduplication of deverbal noun functions as subject or object in the sentence in Javanese. In addition, Yuniartati et al., (2017) wrote about Deverbal noun on syntactic functions found in Huffington Post Website.

The researcher has not found research on deverbal nouns in Madurese. Whereas, there are four affixes found in Madurese which is able to form verbs into nouns after or before they attach to the root.

\section{THEORETICAL FRAMEWORK}

\section{Nominalization (Deverbal Noun)}

Noun that is derived from verb is called deverbal noun (nominalization). Deverbal nouns have a varied range of meanings when prefix is added before the root and suffix after the root (Quirk, 1973). It is also able to change the word category and meaning, such as; invite (verb) + -ion (suffix marking to noun) = invitation (noun). The noun that is derived from verb referred as deverbal. Then, the result of affixation process is called as deverbal noun.

Nominalization is a type of grammatical metaphor which process is realized by a metaphorical verb, which is also realized by a noun expressing the same process as a verb. In this way, the function of the word will change automatically after undergoing nominalization process (Junic, cited in Adu, 2015, p. 5-6). According to Adu (2015), nominalization is one of alternative way to restructure or rephrase a linguistic item such as a verb and turn it into a noun by adding affixes. On the same way, Madurese also have its own affixes to form a noun from verb. Most of Madurese use both prefix and suffix to modify verb to noun, whether in spoken or written. In Madurese, to create noun from verb, it is mostly done by adding both prefix and suffix (Davies, 2010). The instances of each are listed as follows:
1) Massa' 'cook'
= massa'an 'cooked food'
2) Sassa 'wash clothes'
= sassa'an 'laundry'
3) Pekker 'think'
= pekkeran 'thought/idea'

(Davies, 2010, p.112)

Creating new lexemes from verb to noun is called 'nominalizer'. By adding prefix, suffix, confix, and infix in the base form of verb, the word category changes to the noun. In terms of Morphology, when adding a suffix or prefix before and after the root, the class category and its meaning will change, it is known as Derivational Affixes. Haspelmath and Sims (2010), cited in Lestari (2020), stated that the meaning of nouns derived from verb becomes agent, instrument, abstract, action and action noun.

Many of linguists argued that affixation is to form new words, and a root is put together with prefix or suffixes. It had been strengthened by Carstairs-Carthy (2002), that affix is an umbrella of suffixes and prefixes to shape new words. Similarly, Katamba (1993) assumed that affixes are bound morpheme which occurs when root, 
stem or base are followed by suffixes or prefixes. Affixes such as $-s$, -ed or al do not have meaning and cannot stand by its own.

Indeed, affixation will occur in all languages, including Madurese. It had already been mentioned by Linguists that affixation appear in all languages, such as French, Spanish, German, Latin, Russian, Arabic and another Indo-European (Lieber, 2010). Further, Igaab and Kareem (2018), also defined that one of way to create new words is by adding affixes. Therefore, adding affixes before and after root can make it becomes a complex word that still has meaning and can be understood as well. It is supported by (Crystal (cited in Abrar, 2014, p.17) which indicates that, bound morpheme is affixes that commonly always join a root or stem before and after it.

As far as this is concerned, investigating language is beneficial and necessary to maintain that language. As well as examining Madurese, this is a part of local language that must be maintained. Azhar, (2012) argued that Madurese is a local language which is rich of uniqueness and characteristics that other languages do not have. Furthermore, some uniqueness aspects that Madurese has are in phonology, morphology, and syntax. So, this is Madurese must be maintained.

Dealing with morphological process that produces new words through affixation process, such as prefixes, suffixes, infix, etc, it is clearly stated that morphological process is categorized into inflection, derivation and compounding. Lieber ( 2010, p.88) defined that inflection refers to word formation that does not change the word category and meaning and does not construct new lexeme. Whereas Carstairs-Carthy (2002) argued that inflectional morphology contracts to the inflected forms of words, that is the kind of variation that words exhibit on the basis of their grammatical context. Inflectionally, for any noun lexeme such as bird, there are two grammatical words that can change this noun lexeme, "singular and plural noun". A singular form of noun lexeme bird which only consists one morpheme, and a plural form of birds which consists of a root bird and there is additional suffix $-s$ after the root.

From both two expert linguists, they described that inflectional affixes do not change the meaning of the lexeme or the base word. They also do not create new lexeme, but merely change the form of lexemes such as from a singular into plural noun and from present into past tense.

\section{RESEARCH METHODS}

The method of this research is descriptive qualitative method. Since this research is taken from words rather than number, it is considered as qualitative research. Qualitative research is used to examine something related to social phenomena. In this study, the researcher is a key instrument (Sugiyono, 2009). According to Miles and Huberman (1994), a qualitative research is a study that discusses social phenomena by comparing, differentiating, analyzing, classifying, describing and also comparing one object with another. The data source is taken from the vocabulary in the short story book Tora (satengkes carpan Madura) written by Jamal D. Rahman in 2017. The technique used in data collection is reading technique, noting the words containing deverbal nouns and then classifying them based on the affixes which attaches to them. In order to know the process of morphological rule of the occurrence of each affix forming deverbal noun in short story book Tora (satengkes carpan Madura), it needs a morphological tree to break down the affixes which attach to the root. 


\section{RESULTS AND DISCUSSION}

\section{Derivational Process of Deverbal Nouns}

Deverbal Nominalization is the process of forming verb to noun. There are four affixes found in this short story to form verb to noun, that is one prefix, nine suffixes, one infix and one confix. In the tables, the researcher provides the affixes found in the short story:

Table. 01 Affixes in Short Story of Tora

\begin{tabular}{|c|c|c|c|}
\hline Prefix & Suffix & Infix & Confix \\
\hline Panga & $-a n$ & $S e-$ & Ka-, -ngan \\
\hline- & - & - & $K a-,-a n$ \\
\hline- & - & - & $P a-,-a n$ \\
\hline- & - & - & $P a-$, -dha \\
\hline- & - & - & $K a-$, en \\
\hline
\end{tabular}

Prefix that is forming noun from the prefix $p a$ - is called as nominal prefix. Even though there are many prefixes found in Madurese, the researcher only found one prefix, that is prefix $p a$ - in the short story of Tora.

The following is the data that was found in the data source:

1. Prefix pa-

Pangaterro andhi' manto sogi.... (p.333)

The bold word, lexeme of pangaterro is the example of word that gets the attachment of the prefix panga-. The morphological tree diagram is as follows:

a. Pangaterro

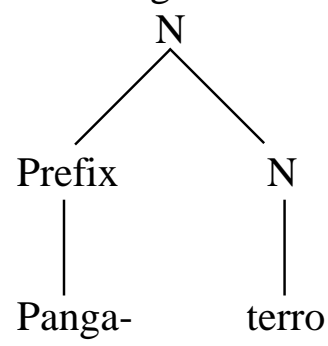

The data shows that one of the base word gets the prefix pa-to change the verb into a noun. The word terro (want) becomes pangaterro (wish,dream) after getting prefix panga-. Furthermore, the verb terro changes the word class and function in the sentence after getting prefix panga-. Noun formed the morphological process is abstract noun. 


\section{Suffix (-an)}

pekkeran se terros agumantong (p.326)

The word typed in bold is deverbal noun. The morphological process is

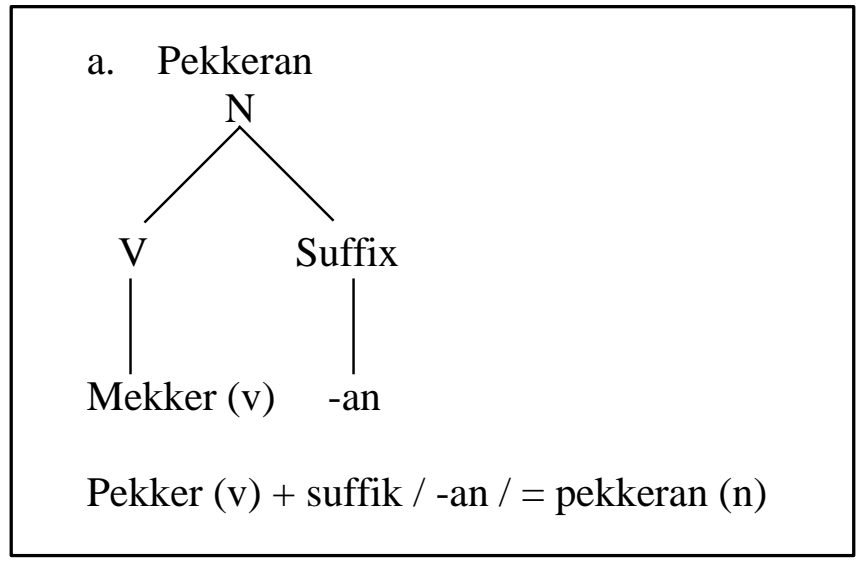

From the diagram, the tree diagram shows the attachment of the suffix -an after the base word, creating new lexeme which belongs to the different word class of the base. The base is from the verb mekker. As a result, the root of the word pekkeran is mekker. Phoneme $\mathrm{m}$ in the root mekker will change into bilabial " $\mathrm{p}$ " if attached to the root starting with the phoneme $/ \mathrm{m}$ and b/. The root word is a verb, which means "to think". Then, the word changes its meaning to "idea" after getting the suffix -an. As the suffix which is also able to change the word category, after getting the suffix -an, the word class from the root of the word pekker, which is a verb, changes to an abstract noun. According to Davies, (2010), the suffix -an is "an activity or result of $X$.

\section{Confix (ka-an)}

...ngagunge bennya' kadhatengan (p. 331)

The word typed in bold is deverbal noun. The morphological process is provided.

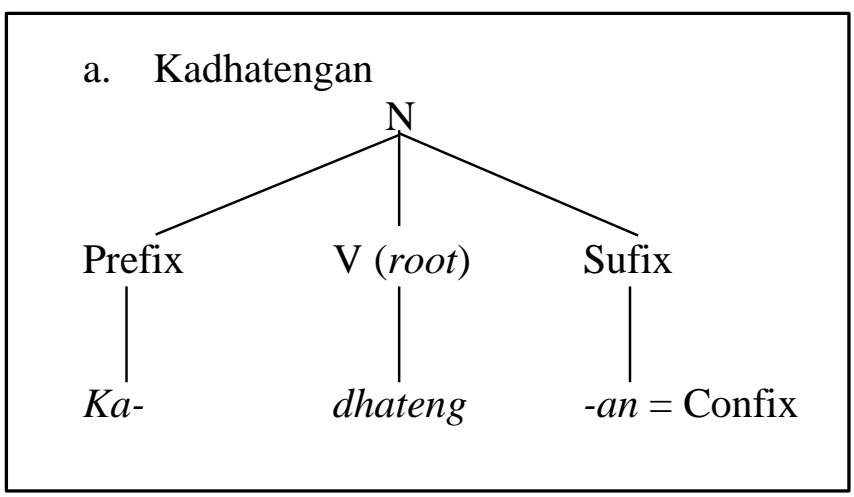

Kadhatengan (Ka-dhateng -an), the word above is one of the deverbal noun that gets the confix $k a--a n$

Dateng (v) + confix / ka -an / = kadatengan (n) 
The diagram shows that when confix attaches to the root of the word dateng (come), which the root is a verb. However, the word class will change to noun after getting additional confix $\mathrm{ka}$ - dhateng- an (arrival). In addition, it is already mentioned that adding affixes will change the meaning and the function of word classes. Thus, when the meaning of the word changes, the function of word classes automatically change. Davies, (2010) stated that when confix $(k a-a n)$ when attaches to a verb, it becomes noun.

\section{CONCLUSION}

The conclusion of this research is there are four types of affixes in Madurese, those are; prefix, infix, suffix, and confix (prefix and suffix). When Madurese affixation attaches to the basic form, it can cause morphological, phonological and semantic processes in the formation of the process. The most affixation which is found in short story entitled Tora (satengkes carpan Madura) is confix. It is shown that confix contributes the most to the process of nouns derived from verb. The function of nominalization is to change the word class category, such as; verbs to nouns. Besides of being able to change the function of the word class, it can also change the meaning as explained above.

\section{REFERENCES}

Adu, S., K. (2015). Nominalizations In Research Article Abstracts: A Comparative Study. European Journal Language Studies, 2 (1), 2057-4797.

Bauer, L. (1983). English Word-Formation (1st ed.). Cambridge University Press. https://doi.org/10.1017/CBO9781139165846

Davies, W. D. (2010). A grammar of Madurese. De Gruyter Mouton.

Grimshaw, J. (2020). Deverbal nominalization . Cambridge University Library. https://doi.org/10.1515/9783110589443

Herawati, N. (2016). Affixed Reduplication Forming Deverbal Noun In Javanese Language. 6.

Jamal D. Rahman. ( 2017). Tora : satengkes carpan Madura.

Lieber, R. (2010). Introducing Morphology. Cambridge University Press. https://doi.org/10.1017/CBO9780511808845

Miles, M. B., \& Huberman, A. M. (1994). An expanded sourcebook: Qualitative data analysis (2nd ed.). United States: SAGE Publications.

Muslimah, D., Nurhayati, E. A. A., \& Suhartatik, S. (2019). Afiksasi Bahasa Madura Dialek Sumenep Tingkat Tutur Rendah. Estetika: Jurnal Pendidikan Bahasa Dan Sastra Indonesia, 1(1), 19-30. https://doi.org/10.36379/estetika.v1i1.3

Oktavianti, I. N., Chaerani, N., \& Prayogi, I. (2019). Analisis Kontrastif Nominalisasi dalam Bahasa Inggris, Bahasa Indonesia, dan Bahasa Jawa. Sasdaya: Gadjah Mada Journal of Humanities 
Quirk, R. et., al. (1973). A Grammar Contemporary of English. Longman.

Sugiyono. (2009). Metode penelitian kuantitatif dan kualitatif dan R \& D. Bandung: Alfabeta.

Yuniartati, M. D., Udayana, I. N., \& Aryawibawa, I. N. (2017). Syntactic Functions of Deverbal Nouns Found in Huffington Post Website: Morphosyntactic Approach. 19, 9. 